the stalls by a red star. As compared with last year, the exhibits in the Research Section have nearly doubled, while those in the Trade Section are about the same with a somewhat larger proportion of red stars. Some of the illustrations convey more information as to the working parts of the instruments than in past years, and are more useful to prospective buyers. Those on pp. 28, 165, 176 and 179 may be taken as examples. Discourses were delivered on January 4 by Captain G. C. C. Damant on "Diving in Deep Water and Shallow", on January 5 by Prof. A. F. C. Pollard on "Mechanical Amplification of Small Displacements" and by Sir Richard Gregory on "Science and Citizenship" jointly to the visitors to the Exhibition and to those attending the Exhibition of School Apparatus by the Science Masters' Association.

\section{Engineering and Economics}

IN an address to the Society of Engineers on October 4, entitled "Engineering and the New Economics", Dr. H. Chatley suggested that the engineer can contribute to the solution of economic problems of to-day in three ways. In the first place, the engineer can study the problem in terms of realities, such as goods, energy and services, and endeavour to disentangle them from the cobwebs of finance. Secondly, some engineers by entering politics can assist in spreading ideas on the realities of life. Thirdly, the engineer both by speech and by writing can help to explode some old fallacies and to educate the public in newer ideas and especially in that of the impartial application of scientific method to public affairs. Dr. Chatley illustrated his argument in respect of the last point by outlining in some detail the way in which the engineer can assist in the development of a sound fiscal policy in regard to coal and oil as well as in regard to the prevention of atmospheric pollution, the preservation of amenities, the question of values and prices, international debts, and population limits, and concluded by asserting that it is the duty of the engineer to understand the problems which have been raised by the misapplication by others of his skill. Scientific method should play an important part in citizenship since the classification of facts, the recognition of their sequence and significance and the habit of forming an unbiased judgment upon the facts which are characteristic of the scientific frame of mind are also essentials of good citizenship.

\section{Awards for War Inventions}

THE final report of the Royal Commission on Awards to Inventors, which has now been published (Cmd. 5594) shows that, in all, 1,834 applications were received by the Commission, of which 369 were dealt with by the Commission direct. Of the remaining 1,465 , which were in the first instance considered by the Investigating Committee, 846 were withdrawn or apparently abandoned, 75 were referred to and later heard by the Commission and 544 were rejected by the Committee as having no reasonable chance of success. In 200 of them the claimant exercised his right of a personal appearance before the Investigating Committee. The total amount of awards was about $£ 1,500,000$, and a summary of the awards is appended to the report. Claims submitted to the Commission before the final date fixed by Royal Warrant (March 31, 1932) were virtually determined by December 31,1933 , but there were at that date certain claims the position of which had not been finally determined. The claims in question have since been otherwise disposed of, but while further sittings of the Commission were not necessary, the submission of a final report was delayed. The actual sittings of the Commission covered a period of fifteen years, and in that time the Commission lost by death its chairman, Lord Tomlin, as well as two members, Mr. A. C. Chapman and Prof. W. E. Dalby.

\section{Commonwealth Fund Fellowships}

Thurty-Four of these fellowships, enabling British university men to devote two years to study and travel in the United States of America, are offered for award in 1938. Twenty-four are open to candidates of British descent, domiciled in the United Kingdom, who are graduates of universities therein, unmarried and less than thirty years of age; two to graduates of a university in a British dominion or colony; five are 'service fellowships' open only to candidates holding Government appointments in the British Empire over-seas ; and three are Home Civil Service fellowships. The Committee of Award (chairman, Sir Walter H. Moberly) give primary consideration to intellectual ability, personality and initiative; account is also taken of character and health. Application, in the prescribed form, approved by the authorities of the college or university of which the candidate is or has been a member, must reach the Secretary to the Committee (35 Portman Square, W.1) by February 1. In 1937, awards were made to candidates from Cambridge (5), Cardiff, Glasgow, Liverpool (2), London (4), Manchester (2), Oxford (9), Reading, St. Andrews, New Zealand and South Africa. The subjects of study were very various, comprising: physics (3), chemistry (2), biophysics, zoology, physiology, medicine (2), engineering, architecture (2), law, political science, economics, international relations, education, modern languages, English literature, American literature, theology. The fellowships, in some respects complementary to the Rhodes scholarships, were established with the view of promoting mutual amity and understanding between Great Britain and the United States.

\section{Constable's Portrayal of Weather}

Mr. L. C. W. Bonacina's paper on "John Constable's Centenary: His Position as a Painter of Weather" (Quart. J. Roy. Meteor. Soc., October 1937) is a notable contribution to that affiliation of the Nature studies of the artist and scientific worker which is so much to be desired. The character of the country in which Constable was born and bred evidently influenced his practice of emphasizing cloud effects in landscape. The Suffolk countryside where the celebrated pictures of Flatford Mill, Dedham Mill and Stoke-byNayland were painted is the plain seen by the traveller on the London and North-Eastern Railway when 
crossing the River Stour above Manningtree. Here the land presents none of those emphatic forms which in rugged scenery tend to concentrate attention on the lower half of the confronting hemisphere, so the eye ranges freely over the sky, and the cloud is as important as the field in the composition of the picture. Originals of Constable's paintings are readily accessible in the National Gallery and the Victoria and Albert Museum, and many are familiar as engravings, so that Mr. Bonacina's judgments can easily be tested. We welcome his conclusion that Constable's generalization of particular types of cloud in a manner not possible for photography is of service to the meteoro. logist. The analysis of certain pictures in which transitory forms are so perfectly depicted as to introduce a cinematic effect is a notable contribution to art criticism. It is indeed entirely appropriate that the student of natural science should thus contribute to the understanding of landscape painting, for the critical faculty is as a rule more highly developed in the man of science than in the artistwho does more than he knows.

\section{A Guide to Fishes}

REGULAR visitors to the Fish Gallery at the British Museum (Natural History) during recent years have watched with interest the rearrangement under the supervision of Mr. J. R. Norman. The large number of new casts and models, due to the skill of Mr. S. Stammwitz, have resulted in an exhibition illustrative of fish life that would be difficult to improve upon with present-day resources. The first part of the new guide to the Gallery contains a general account of classification, the scheme adopted being that proposed by Dr. C. Tate Regan (British Museum (Natural History). Illustrated Guide to the Fish Gallery. By J. R. Norman. Pp. $\mathrm{x}+175+6$ plates. London : Trustees of the British Museum, 1937. 1s. 6d.). A wealth of interesting notes on habits and on fisheries turns what might otherwise be a rather dull catalogue into fascinating matter for general reading. The second and rather larger portion of the book is taken up with descriptions of the special exhibits, of which there are eighteen. These are evidently such as will cater for the needs of most visitors. They include such items as the crucifix fish, of interest to the credulous rather than to the serious student, who will find more to his taste in the section (and exhibit) devoted to breeding habits and development of coloration. This is an excellent guide book, but it is more than that; it is an elementary text-book of fish life. It is well written and well illustrated, in which connexion a word of praise must be spared for Lieut.-Col. W. P. C. Tenison's accurate and charmingly executed drawings.

\section{The School Certificate Examination}

THE School Certificate Examination, its merits and demerits and how it might be improved: these are matters which so closely concern so many peopleparents and employers as well as school and university teachers and administrators-that the National Union of Teachers has performed an important public service in printing and circulating Sir Philip Hartog's address at its Portsmouth Conference. Sir Philip, than whom a more competent critic could scarcely be found, exposes manifold weaknesses of the examination as at present administered. He discusses such questions as: What does passing the examination imply in terms of what each successful candidate will be able to do ? What do the examiners suppose they are trying to test ? What of the validity and consistency of the test ? More than a quarter of the candidates fail : does this not point to serious maladjustment between education and examination? He makes five definite proposals for reform: (i) classify tests in such a way as to show employers in what cases they can rely on a pass as showing the possession of definite utilizable skills; (ii) give to each candidate a certificate characterizing his or her performance in each subject; (iii) abolish the group system in so far as it hampers the school in determining the examination programme to suit each child after investigation of individual aptitudes; (iv) supplement the school certificate by a cumulative school record; (v) protect certain subjects, such as English literature, history and general science, from examination pressure, providing at the same time for their compulsory inclusion in the curriculum and school time-tables.

\section{Gardens for Busy Enthusiasts}

There must be a considerable body of garden enthusiasts who have only a limited time in which to maintain horticultural beauty around their homes. Professional cares of the specialist often diminish the hours of leisure which might be devoted to gardening, or other causes may intervene. Mr. R. S. Lynch's paper on "Gardens of Easy Maintenance" ( $J$. Roy. Hort. Soc., 62, 9, 377-393, Sept. 1937) is a most useful help for such enthusiasts. Lawns are particularly insistent in their demands for attention, and for those who regard them as essential to garden beauty, Mr. Lynch has many suggestions for their more facile control. A pleasing arrangement of alpines upon a paved bank requires little attention, though it ministers well to formal artistry. The horticultural qualities of many perennial plants which demand neither pruning, frequent division, nor staking, are discussed in detail in the paper, whilst the claims of an evergreen garden are also considered. A large amount of practical information, which should help to meet a pressing modern need, is here portrayed.

\section{Timber Seasoning in Australia}

Timber seasoning has made very considerable progress in many countries of the world since the Great War. It was during that War that a great deal of research work in seasoning by means of kiln-drying was undertaken, more especially perhaps in Great Britain and in India. Owing to the enormous consumption of timber upon the War fronts all seasoned material was absorbed in a comparatively short space of time; and since then it is not an overstatement to say that good seasoned material of high quality is very difficult to obtain for many species of timbers. In this new departure of utilizing the kiln for drying 